\title{
寒冷地におけるホタルイ類雑草の種子生産量に及ぼす播種時期, 遮光程度および落水処理の影響*
}

\author{
住吉 正 $^{* *} \cdot$ 佐藤陽一***
}

要 約: 寒冷地におけるホタルイ類雑草の種子生 産量に及ぼす環境要因の影響について秋田県大曲市 のポット条件で検討し，以下の結果を得た。

1）無遮光条件下ではイヌホタルイおよびタイワ ンヤマイともに播種時期が遅れるにしたがって種子 生産量が減少したが，8月上旬の播種でも若干の種 子生産が認められた。また, 遮光処理によって種子 生産量が減少し, 遮光が強いほど影響が大きかった。 そのため, 8 月上旬播種ではイヌホタルイは遮光率 65\% および 35\%で，タイワンヤマイは遮光率 65\% でそれぞれ種子生産が認められなかった。

2）収穫時期における茎数はイヌホタルイおよび タイワンヤマイともに播種時期が遅いほど, 遮光が 強いほど少ない傾向を示した。また, 茎数, 茎乾物 重および種子生産量のそれぞれの間に高い正の相関 が認められた。

3）生育期間中に 1 カ月間の落水処理をしたイヌ ホタルイの種子生産量は, 常時湛水条件下で生育し たものに比べて減少し, 落水処理の時期によっても 種子生産量が異なった。また, 落水処理は種子成熟 の推移に影響した。

4）常時湛水条件下で生育したイヌホタルイの種 子千粒重は, 5 月中旬〜 6 月上旬播種では採種時期の 遅いものほど軽い傾向を示したが, 6 月下旬〜 7 月上 旬播種では採種時期の遅いものほど重い傾向を示し た。

キーワード : イヌホタルイ, タイワンヤマイ, 種子 生産量, 遮光, 落水処理

\footnotetext{
* 一部は日本雑草学会第 29 回大会 (1990 年 4 月)において 発表した。

** 農林水産省東北農業試験場, 現在, 九州農業試験場

*** 秋田県神岡町

(1996 年 3 月 11 日受理)
}

\section{緒言}

ホタルイ類雑草は東北地域および北海道に発生が 多いカヤツリグサ科の水田多年生雑草で, 種子およ び越冬芽で繁殖する。一般に「ホタルイ」と呼ばれ, 東北地域の水田ではイヌホタルイ (Scirpus juncoides Roxb. subsp. juncoides) とタイワンヤマイ (S. wallichii Nees) が比較的多く分布している ${ }^{10)}$ 。

ホタルイ類雑草の越冬芽は水田内では冬季間の乾 燥や秋耕，また，代かき時の土壤中への埋没によっ て防除可能である ${ }^{4,13)}$ が, 一方, 種子は毎年大量に生

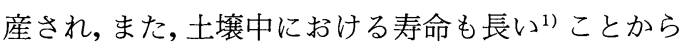
水田内における繁殖の主体は土壌中に多量に蓄積さ れた種子である。したがって, ホタルイ類雑草の防 除のポイントは, 種子発生の防止と土壤中の種子量 の減少とに集約される。このうち, 後者の埋土種子 量の減少に関しては, 新たな種子生産の防止という ことが栽培管理上最も重要と考える。

ホタルイ類雑草の種子生産に関しては温暖地では 岩崎 ${ }^{6)}$, 小山( ${ }^{7)}$ および渡辺ら $^{14)}$ の報告, 暖地では坂本 $ら^{8,9)}$ の報告があるが, 寒冷地においては高野ら ${ }^{13)}$ の報告があるのみである。しかし, 高野ら ${ }^{13)}$ の報告 では「ホタルイ」の種が特定されておらず, また, 調 査条件も限られていることなどから，防除を目的と した生態的特性の解明には至っていない。そのため, 寒冷地におけるホ夕ルイ類雑草の種子生産に関して は以上の点を明確にした試験が必要と考えられた。

本研究の目的は, 寒冷地水田におけるホ夕ルイ類 雑草の種子生産量について発生時期および生育環境 (遮光拉よび落水条件)との関係から明らかにするこ とである。なお, 本報でいう種子とは厳密には果実 のことである。また, 引用文献でホ夕ルイ類雑草の 種が明記されていないもの, および坂本ら ${ }^{9}$ の材料 である「イヌホタルイに類似したホタルイ属内の交 雑種」については便宜上すべて「ホタルイ」として 
記載し，引用した。

\section{材料および方法}

\section{試験 1 ：播種時期および遮光処理の影響}

試験は 1985 年および 1986 年に行った。イヌホ夕 ルイおよびタイワンヤマイの種子は播種前年に東北 農業試験場栽培第一部（秋田県大曲市，現在水田利 用部)の試験围場において採集したものを用いた。種 子は 5 $10^{\circ} \mathrm{C}$ の湛水土壌中に貯蔵して休眠覚醒させ た後，所定の日（1985年は 5 月 24 日〜 7 月 31 日， 1986 年は 6 月 10 日〜 8 月 11 日）にシャーレ内の湿 潤乃紙床に播種し， $30^{\circ} \mathrm{C}$ の恒温器内で発芽させた。 播種 3〜4 日後に，約 $0.5 \sim 1$ 葉に生育したものを水 田土壤を詰めて湛水代かき状態とした $1 / 2,000 \mathrm{a}$ ポットにそれぞれ 4 個体あて移植した。ポットは屋 外で管理し, 1985 年は 7 月 10 日から, 1986 年は 7 月 14 日から寒冷紗を用いて遮光率 65\%，35\% および $0 \%$ (無遮光区) の条件下で試験終了時まで栽培した (各区 2 ポット)。種子落下前に袋掛けを行い, 周辺 地区での水稲の収穫が終了する 10 月下旬に地上部 を刈り取ってポット当たりの茎数, 茎乾物重, 種子 風乾重（全重）抢よび種子千粒重を調査した。種子 千粒重は果実 100 粒の重量を 4 反復で測定し，算出 した。なお，1985 年は無施肥，1986 年は元肥として ポット当たり, 窒素, リン酸, カリを各 $1.3 \mathrm{~g}$ ずつ施 用した。

\section{試験 2 : 落水処理の影響}

試験は 1987 年および 1988 年に行った。前記試験 圑場に扔いて採集し，ポット栽培によって系統保存 したイヌホタルイ 1 個体から採取した種子を用い て，試験 1 と同様に休眠覚醒させた後，所定の日 （1987 年は 5 月 30 日，6月 19 日および 7 月 9 日， 1988 年は 5 月 15 日， 6 月 4 日および 6 月 24 日）に シャーレ内の湿潤ろ紙床に播種し， $25 / 15^{\circ} \mathrm{C}$ 昼夜変 温の恒温器内で発芽させた。播種 7 15 日後に, 約 1〜2 葉に生育したものを $1 / 2,000$ a ポットにそれぞ れ 2 個体あて移植した。ポットは 1987 年は屋外, 1988 年は雨よけハウス内で管理し, 各播種日のもの について，第 1 表に示す約 1 力月間の落水処理を 行った(各区 4 ポット)。落水はポットの栓を抜くこ とで行い，それ以外の期間㧍よび常時湛水区（無処 理区） は常時 3〜 $5 \mathrm{~cm}$ の湛水とした。種子は 7〜10 日ごとに各小穂を指で軽く押さえることによって採
第 1 表 落水処理の期間（試験 2)

\begin{tabular}{|c|c|}
\hline 播種日 & 落水処理の期間 \\
\hline 1987 年 5 月 30 日 & 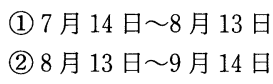 \\
\hline 6月 19 日 & 8 月 3 日〜 9 月 7 日 \\
\hline 7月 9 日 & 処理せず \\
\hline 1988 年 5 月 15 日 &  \\
\hline 6 月 4 日 & 7 月 24 日〜 8 月 22 日 \\
\hline 6 月 24 日 & 8 月 13 日〜 9 月 11 日 \\
\hline
\end{tabular}

集し，各採集日ごとに種子風乾重および種子千粒重 を試験 1 と同様に調查した。なお，両年とも元肥と

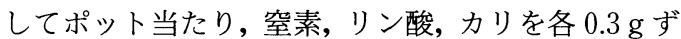
つ施用した。

石倉・曽我 ${ }^{2)}$ はイヌホタルイ種子の稔実程度を種 皮色に基づいて 3 期に類別し，(1) 緑色：未熟(開花 後 15 日まで)，(2) 緑褐〜茶褐：中熟（同 20 日～30 日),(3) 黒蝎〜黒色: 完熟（同 35 日以降）とし，開 花後 20～25 日頃に発芽率 50\% 以上の発芽能力と休 眠性が備わることを示した。したがって，本試験で は種皮色が褐色〜黒色の中熟〜完熟にあたる種子を 調査対象とし，白色〜黄色のものは未熟と考えられ るため除外した。また，種子生産量（種子数）は種 子風乾重と種子千粒重から換算して求めた。

\section{結果}

\section{試験 1：播種時期および遮光処理の影響}

イヌホタルイおよびタイワンヤマイの種子生産量 に及ぼす播種時期および遮光処理の影響についての 結果を第 1 図に示した。遮光率 $35 \%$ 区の種子生産量 は概ね無遮光区と遮光率 $65 \%$ 区の中間的な值を示 したので煩雑なため結果の図からは省略した。両種 ともに種子生産量は播種時期が遅いほど少ない傾向 を示した。また, 遮光によって種子生産量は減少し, 遮光率が高いほど減少量が大きい傾向を示した。ま た, 1986 年の 8 月 11 日播種では,イヌホタルイは遮 光率 $65 \%$ および $35 \%$, タイワンヤマイでは遮光率 65\%で結実しなかった。

無遮光区で最も種子生産量が多かったのは，1985 年はいずれも 5 月 24 日播種でイヌホタルイは約 1,700 粒/個体, 夕イワンヤマイは約 2,300 粒/個体, 1986 年はいずれも 6 月 30 日播種でイヌホタルイは 



第 1 図 ホタルイ類雑草の種子生産量に及ぼす播種時期および遮光処理*の影響

注）記号は, 一○一イヌホタルイ,一一タイワンヤマイ, - - - 無遮光区, --- 遮光率 $65 \%$ 区。

約 2,000 粒/個体, タイワンヤマイは約 3,500 粒/個 体で，両年ともタイワンヤマイの方が多かった。ま た，各播種日および遮光処理条件下での種子生産量 をイヌホタルイとタイワンヤマイで比較すると，概 してタイワンヤマイの方が種子生産量が多かった。 種子生産量が年次間で異なったことに関しては施肥 条件の違い（1985 年は無施肥）や気象条件の違いな どが考えられる。

1985 年 6 月 6 日播種では遮光区の種子生産量が 無遮光区を上回った。イヌホタルイでは同日播種の 無遮光区の種子生産量が他の播種日に比べて極端に 低下しており，何らかの異常があったものと考えら れるが，原因は不明である。

収穫時期におけるイヌホタルイおよびタイワンヤ マイの茎数に及ぼす播種時期および遮光処理の影響 についての結果を第 2 図に示した。両種ともに, 茎 数は播種時期が遅いほど, また, 遮光が強いほど少 ない傾向を示し, 概してタイワンヤマイの方がイヌ ホタルイよりも茎数が多かった。また, 播種時期の 違いによる茎数の変動は 1986 年の方が 1985 年より
も大きかった。収穫時期における個体当たりの茎乾 物重は茎数とほほ同様の傾向であった（デー夕省 略)。

各播種時期別に茎当たりの種子着粒数を, 種子生 産量および茎数から算出して第 3 図に示した。茎当 たりの着粒数は播種時期の遅いほど少ない傾向を示 し,特に 1985 年でその傾向が顕著であった。しかし, 茎当たりの着粒数に対する遮光処理の影響は一定の 傾向を示さなかった（データ省略）。

以上のことから, 播種時期の遅れや遮光による種 子生産量の減少には茎数の減少が大きく影響したと 考えられ,一部では茎当たりの着粒数の減少も影響 したと考えられた。

播種時期と種子千粒重との関係を第 4 図に示し た。1985 年の結果ではイヌホタルイおよびタイワン ヤマイともに播種時期が遅くなるにしたがって種子 千粒重が増加する傾向がみられたが, 1986 年の結果 では一定の傾向はなく, 種子千粒重に対する播種時 期の影響は不明であった。また，種子千粒重に対す る遮光処理の影響も一定の傾向を示さなかった 
a ) 1985 年

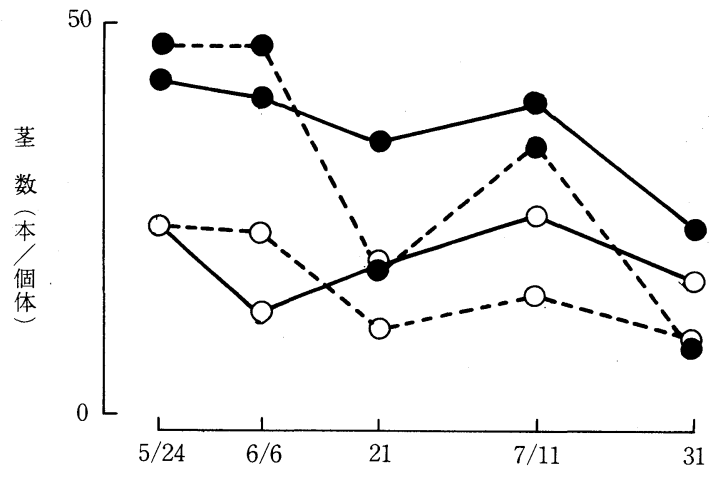

b ) 1986 年

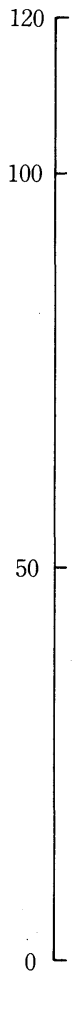

b) 1986 年

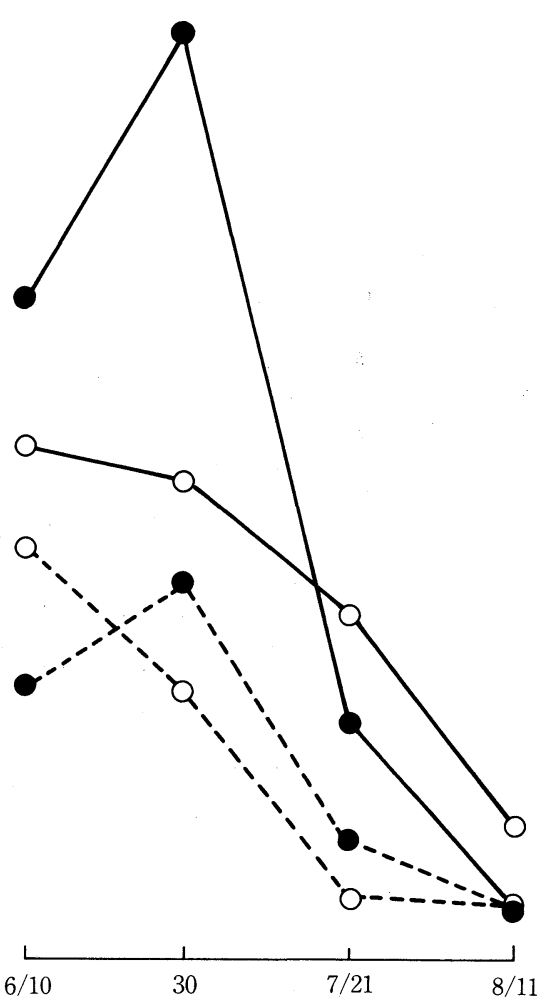

播 種 時期 (月/日)

第 2 図 ホタルイ類雑草の茎数に及ぼす播種時期および遮光処理* の影響

注）記号は，一○一イヌホタルイ，一○一タイワンャマイ，*—無遮光区，-- 遮光率 $65 \%$ 区。

(デー夕省略)。

試験 2 : 落水処理の影響（第 2 表，第 3 表）

イヌホタルイの種子生産量は試験 1 の結果と同様 に播種時期の遅いほど少なくなった。また, 各播種 時期とも落水処理によって種子生産量が減少した。 常時湛水区の種子生産量は, 1987 年 5 月 30 日播種 では 5,300 粒/個体, 1988 年 5 月 15 日播種では 7,300 粒/個体で，いずれも試験 1 の結果よりもかな り多かった。これにはポット当たりに移植した個体 数の違い（試験 $1: 4$ 個体/ポット, 試験 $2: 2$ 個体/ ポット) やポットの管理条件（1988 年は雨よけハウ ス内, その他は屋外), 気象条件などが影響したもの と考えられる。また, 1987 年の結果に比べて, 1988 年の落水処理による種子生産量の減少割合が大き かったが,これは 1987 年は屋外で管理し, 1988 年は 雨よけハウス内で管理したため, 1988 年の落水処理
区では土壌が極端に乾燥してイヌホタルイの生育が 停滞したためと考えられる。

各採取日ごとの種子採集量によって種子成熟の推 移をみると, 常時湛水区における種子成熟のピーク 時期は播種時期が遅いほど遅れた。落水処理による 影響は 1988 年に顕著に認められ，5月 15 日播種お よび 6 月 24 日播種では種子成熟のピーク日が移動 し, 5 月 15 日播種の落水区 (2)では 9 月 10 日〜 30 日 の種子採集量が極端に少なくなった。

種子千粒重は播種時期の遅いほど大きくなる傾向 が認められた。常時湛水区における各採取日ごとの 種子千粒重をみると, 5 月中旬〜 6 月上旬播種では採 取日の遅いほど軽くなる傾向がみられたが，6月下 旬〜 7 月播種では採取日が遅いほど重い傾向を示し た。落水処理区では概水常時湛水区と同様な傾向が 認められたが, 1988 年 5 月 15 日播種の落水区 (2) で 


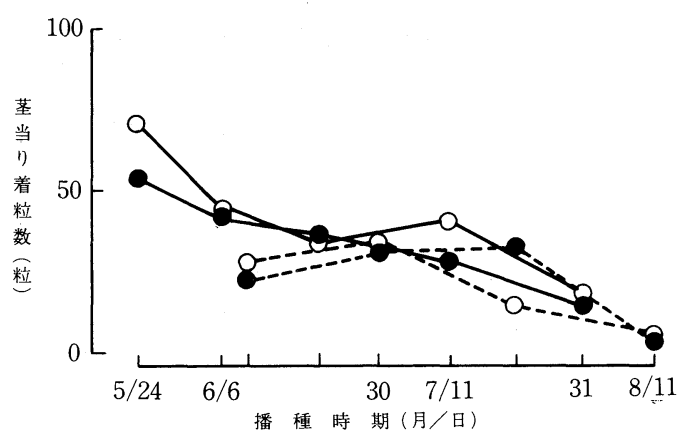

第 3 図 ホタルイ類雑草の茎当りの着粒数に及ぼす播種 時期の影響

注） 記号は，一○一イヌホタルイ，一ー一タワンヤ マイ, - 1985 年, …-1986 年, いずれも無遮光区。



第 4 図 ホタルイ類雑草の種子千粒重に及ぼす播種時期 の影響

注）記号は, 一○一イヌホタルイ,一一タイワンヤ マイ,一-1985 年, -...-1986 年, いずれも無遮光区。

第 2 表 採取時期別のイヌホタルイの種子採集量*および種子千粒重**に及ぼす播種時期および落水処理の影響（1987 年）

\begin{tabular}{|c|c|c|c|c|c|c|c|c|c|c|}
\hline \multirow{2}{*}{$\begin{array}{c}\text { 播種日 } \\
\text { (移植日) }\end{array}$} & \multirow{2}{*}{ 試験区 } & \multicolumn{8}{|c|}{ 種子採取 日 } & \multirow{2}{*}{ 合計 } \\
\hline & & $8 / 28$ & $9 / 7$ & $9 / 14$ & $9 / 21$ & $9 / 28$ & $10 / 5$ & $10 / 12$ & $10 / 26$ & \\
\hline \multirow{6}{*}{$\begin{array}{c}5 \text { 月 } 30 \text { 日 } \\
(6 \text { 月 } 14 \text { 日) }\end{array}$} & 常時湛水区 & 67 & 1263 & $\underline{1819}$ & 834 & 640 & 528 & 187 & - & 5338 \\
\hline & & $(1.54)$ & $(1.57)$ & $(1.46)$ & $(1.30)$ & (1.19) & $(1.01)$ & $(0.95)$ & - & (1.37) \\
\hline & 落水区(1) & 282 & 1110 & $\underline{1347}$ & 599 & 339 & 221 & 56 & - & 3954 \\
\hline & & $(1.60)$ & $(1.53)$ & $(1.33)$ & (1.19) & $(1.06)$ & $(0.96)$ & $(1.01)$ & - & (1.33) \\
\hline & 落水区(2) & 56 & 1091 & $\underline{1189}$ & 784 & 590 & 458 & 235 & - & 4403 \\
\hline & & $(1.56)$ & $(1.60)$ & (1.53) & $(1.44)$ & (1.31) & $(1.05)$ & (1.13) & - & (1.43) \\
\hline \multirow{4}{*}{$\begin{array}{l}6 \text { 月 } 19 \text { 日 } \\
\text { (7月 } 4 \text { 日) }\end{array}$} & 常時湛水区 & - & - & 87 & 157 & 472 & $\underline{680}$ & 535 & 615 & 2546 \\
\hline & & - & - & $(1.45)$ & $(1.62)$ & (1.66) & (1.64) & $(1.55)$ & $(1.50)$ & (1.59) \\
\hline & 落水区 & - & - & 166 & 169 & 375 & $\underline{385}$ & 287 & 246 & 1628 \\
\hline & & - & - & $(1.55)$ & $(1.66)$ & (1.68) & $(1.50)$ & $(1.45)$ & $(1.36)$ & (1.53) \\
\hline 7月 9 日 & 常時湛水区 & - & - & - & 4 & 70 & 249 & $\underline{382}$ & 536 & 1241 \\
\hline （7月 16 日） & & - & - & - & $(1.39)$ & (1.53) & $(1.66)$ & (1.76) & $(1.82)$ & (1.75) \\
\hline
\end{tabular}

注） *上段（種子粒数/個体)，**下段（）内 $(\mathrm{g} /$ 種子 1,000 粒 $)$ 。

各試験区ごとに種子採集量が最も多かった採取日に下線を付した。ただし, 10 月 26 日については採集量の $1 / 2$ を他と 比較した。

は，種子採集量の少なかった 9 月 10 日および 20 日 の種子千粒重は極端に軽かった。

\section{考察}

これまでのホタルイ類雑草の種子生産量に関する 報告では, 渡辺ら ${ }^{14)}$ は温暖地の水稲普通期作におけ るイヌホタルイの種子生産量を, 裸地で最高 9,700 粒/個体, 水稲畦間で最高 100 粒/個体としている。同 様に, 岩崎 ${ }^{6}$ はホタルイ類雑草の種子生産量を, 裸地 条件ではイヌホタルイは 14,600 粒/株, タイワンヤ マイは 19,800 粒/株, 水稲群落内では $1,000 \sim 3,000$
粒/株と推定した。

試験 1 ではイヌホタルイで最高 2,000 粒/個体, 夕 イワンヤマイは最高 3,500 粒/個体の種子生産量と なり，数值はいずれも小さかったが岩崎( ${ }^{6}$ の報告と 同様にタイワンヤマイの方が種子生産量が多い傾向 であった。また, 試験 2 におけるイヌホタルイの種 子生産量は最高 7,300 粒/個体で, 渡辺ら ${ }^{14)}$ の裸地 条件に比較的近い数值であった。各報告によって試 験条件が異なるため直接の比較は困難であるが，寒 冷地におけるホタルイ類雑草の種子生産量は温暖地 普通期作なみか若干少ない程度と推察される。 
第 3 表 採取時期別のイヌホタルイの種子採集量*および種子千粒重** に及ぼす播種時期および落水処理の影響（1988 年）

\begin{tabular}{|c|c|c|c|c|c|c|c|c|}
\hline \multirow{2}{*}{$\begin{array}{c}\text { 播種日 } \\
\text { (移植日) }\end{array}$} & \multirow{2}{*}{ 試験区 } & \multicolumn{6}{|c|}{ 種子採取 日 } & \multirow{2}{*}{ 合計 } \\
\hline & & $8 / 31$ & $9 / 10$ & $9 / 20$ & $9 / 30$ & $10 / 10$ & $10 / 20$ & \\
\hline \multirow{6}{*}{$\begin{array}{c}5 \text { 月 } 15 \text { 日 } \\
\text { (5月 } 22 \text { 日) }\end{array}$} & 常時湛水区 & 1669 & $\underline{2486}$ & 2124 & 786 & 133 & 71 & 7269 \\
\hline & & (1.69) & $(1.57)$ & $(1.30)$ & $(1.06)$ & $(1.03)$ & $(1.06)$ & (1.45) \\
\hline & 落水区(1) & 420 & 846 & $\underline{1422}$ & 719 & 234 & 55 & 3696 \\
\hline & & (1.53) & $(1.47)$ & $(1.41)$ & $(1.25)$ & $(1.28)$ & $(1.36)$ & $(1.40)$ \\
\hline & 落水区(2) & $\underline{817}$ & 165 & 65 & 57 & 252 & 94 & 1450 \\
\hline & & $(1.38)$ & $(0.82)$ & $(0.71)$ & $(1.21)$ & $(1.57)$ & $(1.59)$ & (1.34) \\
\hline \multirow{4}{*}{$\begin{array}{c}6 \text { 月 } 4 \text { 日 } \\
\text { (6月 } 11 \text { 日) }\end{array}$} & 常時湛水区 & 135 & 676 & $\underline{1148}$ & 754 & 423 & 97 & 3233 \\
\hline & & $(1.52)$ & $(1.62)$ & $(1.48)$ & $(1.27)$ & $(1.15)$ & $(1.07)$ & (1.41) \\
\hline & 落水区 & 188 & 320 & $\underline{460}$ & 396 & 356 & 87 & 1807 \\
\hline & & $(1.60)$ & $(1.56)$ & $(1.46)$ & $(1.41)$ & $(1.52)$ & $(1.47)$ & $(1.50)$ \\
\hline \multirow{4}{*}{$\begin{array}{c}6 \text { 月 } 24 \text { 日 } \\
\text { (7月 } 1 \text { 日) }\end{array}$} & 常時湛水区 & - & - & 96 & 339 & $\underline{449}$ & 199 & 1083 \\
\hline & & - & - & $(1.36)$ & $(1.59)$ & $(1.77)$ & (1.81) & (1.69) \\
\hline & 落水区 & - & - & 180 & $\underline{255}$ & 157 & 71 & 663 \\
\hline & & - & - & $(1.51)$ & $(1.55)$ & $(1.53)$ & $(1.50)$ & (1.55) \\
\hline
\end{tabular}

注） *上段 (種子粒数/個体)，**下段（）内（g/種子 1,000 粒)。 各試験区ごとに種子採集量が最も多かった採取日に下線を付した。

第 4 表 イヌホタルイの生育量と種子生産量の相関

\begin{tabular}{l|ccc}
\hline & 茎数 & 茎乾物重 & 種子生産量 \\
\hline 茎 数 & & 0.806 & 0.803 \\
茎 乾 物 重 & 0.970 & & 0.894 \\
種子生産量 & 0.895 & 0.935 & \\
\hline
\end{tabular}

注）上段は 1985 年，下段は 1986 年の相関係数

イヌホタルイに比べてタイワンヤマイの方が種子 生産量が多かったことに関しては，茎当たり種子数 には両種で大差がなかった（第 3 図）ことから，個 体当たりの茎数の差が影響したものと考えられる。 実際，第 2 図に示したように，タイワンヤマイの方

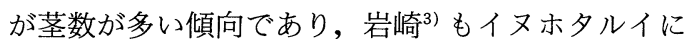
比べてタイワンヤマイの茎数が多いことを認めてい る。

試験 1 の各試験区を込みにしてみた場合, イヌホ タルイおよびタイワンヤマイともに個体当たりの茥 数, 茎乾物重および種子生産量のそれぞれの間には 高い正の相関が認められた(第 4 表, 第 5 表)。この 結果はホタルイ類雑草の種子生産量に対して茎数や 茥乾物重といった個体の生育量が大きく関わってい ることを示している。渡辺ら ${ }^{14)}$ もイヌホタルイの茎 葉部風乾重と種子生産量との間に高い正の相関を認 めている。
第 5 表 タイワンヤマイの生育量と種子生産量の相関

\begin{tabular}{l|ccc}
\hline & 茎数 & 茎乾物重 & 種子生産量 \\
\hline 茎 数 & & 0.901 & 0.892 \\
茎 乾物 重 & 0.945 & & 0.863 \\
種子生産量 & 0.956 & 0.921 & \\
\hline
\end{tabular}

注）上段は 1985 年, 下段は 1986 年の相関係数

岩崎・萩本 ${ }^{5)}$ はホタルイ類雑草の生育 (茎数, 根数 および乾物重など）は遮光率 $42 \%$ ～ $88 \%$ の範囲では 遮光率の高いほど減少することを示し, 茎数に対す る影響はタイワンヤマイで大きく, 出穂に対する影 響はイヌホタルイで大きいことを示した。試験 1 で は遮光処理によってイヌホタルイおよびタイワンヤ マイともに茎数, 茎乾物重および種子生産量が減少 したが, 茥数や種子生産量に対する遮光の影響の草 種間差は明確ではなかった。

また, 試験 2 では落水処理を約 1 力月間行った。実 際の水稲移植栽培において生育期間中にこのような 落水を行うことは通常はなく, ここでみられた結果 は必ずしも実際の条件で反映されるとは限らない。 しかし，落水処理によって種子生産量が影響された という結果は, 中干しや収穫前の早期落水などの栽 培管理や, 用水整備や圃場の水もちなどの圑場条件 によってホタルイ類雑草の種子生産量が影響される 
可能性を示したものと考える。

試験 2 では種子を経時的に採取することによって 種子成熟の推移についても調査した。第 2 表および 第 3 表に示したように, 常時湛水区のイヌホタルイ の種子成熟のピークとなる日は, 播種時期の遅いも のほど遅れた。秋田県における水稲収穫期は概ね 9 月中旬から 10 月上旬であるから，5月中に発生した イヌホタルイは水稲収穫期には種子生産をほほ完了 することができる。しかし， 6 月中旬以降に発生した ものは種子成熟のピークとなる以前に水稲は収穫期 を迎え, 完熟種子の生産量が減少するとともに大半 の種子は未熟のまま落下することになる。

坂本ら ${ }^{9}$ は暖地の水稲早期栽培围場に発生した 「ホタルイ」は，水稲収穫期の 8 月上旬の時点では結 実・登熟の進行途中で, 最終的な種子数の約半数が 結実を終えた状態であることを示した。また，渡辺 $ら^{14)}$ は, 温暖地の普通期栽培の水稲収穫期における イヌホタルイ種子の熟度別割合について, 出芽時期 が遅いものほど完熟種子の割合が減少することを示 した。試験 2 の結果はこれらの報告と類似した結果 であり, 寒冷地の水稲収穫期におけるホ夕ルイ類雑 草種子の熟度別割合は暖地や温暖地と同様な状況で あると推察される。しかし，石倉・曽我 ${ }^{2)}$ によればイ ヌホタルイ種子は開花後 10 日程度のものでも発芽 可能であることが示されており，水稲収穫期までに 完熟しなかった種子であっても翌年の繁殖源となり 得ることが予想され，防除においてはさらに未熟種 子についても考慮する必要がある。

次に種子千粒重に対する影響についてみると，試 験 1 では播種時期と種子千粒重との関係は不明で あったが, 試験 2 では播種時期の遅いものほど種子 千粒重が大きい傾向を示し, また, 種子の採取時期 と種子千粒重との間に一定の傾向が認められた。さ らに，落水処理によって種子の採集量が極端に減少 した採取日のものは種子千粒重も極端に軽かった。

石倉・曽我 ${ }^{2)}$ によれば,イヌホタルイの種子千粒重 は開花後から急激に増加し, 30〜35 日後に最大とな り，未熟種子は軽く，完熟種子は重いことが示され ている。試験 2 の落水処理で種子千粒重が極端に減 少したものについては未熟に近い種子の割合が高 かった可能性が大きいが，その他のものについては 前述のようにいずれも中熟〜完熟種子であり，種子 の熟度による影響とは考えられない。
渡辺ら ${ }^{14)}$ は水稲収穫期のイヌホタルイ完熟種子 の千粒重は裸地区では播種時期が遅いものほど増加 し，水稲畦間区では播種時期が遅いものほど減少し たことを示した。試験 2 の結果は, この渡辺らの裸 地区における結果と同じであった。

住吉 ${ }^{11)}$ は観察によってイヌホタルイの種子の大 きさが小穂上の位置によって異なることを認めた。 すなわち，1 小穂の中では茎に近い部分から成熟が 開始し種子は大きく, 先端に向かって成熟期が遅く なり種子は小さくなっている。試験 2 の 5 月中旬〜 6 月上旬播種の常時湛水区で採取日が遅いほど種子千 粒重が軽くなる傾向がみられたが，これは早い採取 日では茎に近い部分の大きい種子の割合が,また,遅 い採取日では先端に近い部分の小さい種子の割合が それぞれ相対的に高まったためと考える。しかしな がら，播種時期と種子千粒重の関係および試験 2 の 6 月下旬 7 月播種の採取日と種子千粒重の関係に ついては，このことだけでは説明できない。

イヌホタルイについては種子の大きさと発芽率と の関係 ${ }^{12)}$ が，また，草種は異なるがタイヌビエにつ いて種子重と休眠・発芽性および初期生長との関 係 ${ }^{15)}$ が示されており, 種子千粒重の変動が種子の休 眠・発芽に及ぼす影響とともに，種子千粒重の変動 要因に関しては今後の検討課題としたい。

以上のように，イヌホタルイおよびタイワンャマ イともに播種時期（発生時期）が遅いほど種子生産 量が少なく，水稲収穫期における成熟種子の割合が 減少するため，これらの雑草の種子生産防止に関し ては初期防除の重要性が指摘できる。

試験 1 では遮光処理を 7 月中旬から実施し, 遮光 率を $35 \%$ および $65 \%$ の 2 水準として種子生産量を 検討した。東北農業試験場水田利用部において草型 や熟期などの生育特性の異なる水稲品種を栽培した 水田で群落内相対照度を測定した結果では, 地上 5 $\mathrm{cm}$ で 22〜 82\%, 地上 $25 \mathrm{~cm}$ で 45〜 88\% の変異幅を 示した (1995 年 7 月 21 日調査) ${ }^{*}$ 。したがって, 本試 験の条件は水稲生育期の群落内の光環境を概ね反映 したものであり，この結果によって水稲群落内にお けるホタルイ類雑草の種子生産に関して推察するこ とが可能と考える。

第 1 図に示したようにイヌホタルイおよびタイワ

* 橘 雅明 - 伊藤一幸 1996. 平成 7 年度東北農業試験研究 成績・計画概要集一稲作・(栽培) - - p. 294. 
ンヤマイともに種子生産量は播種時期が遅いほど, また，遮光率の高いほど少なかった。そして 8 月 11 日播種では，遮光率 $65 \%$ では両種ともに結実しな かった。高野ら ${ }^{13)}$ も寒冷地の水田裸地条件で 8 月に 出芽した「ホタルイ」は種子形成しなかったことを 報告した。したがうて, 寒冷地水田においてホタル 亿類雑草の種子生産防止といった観点から必要除草 期間を設定する場合には, 7 月下旬(水稲移植約 2 力 月後）が一つの指標となろう。

渡辺ら ${ }^{14)}$ は, 温暖地水稲普通期作においては, 移 植後 1 カ月以上たって水稲畦間に発生したイヌホ夕 ルイの実生個体はほとんど種子生産を行わないこと を明らかにした。実際の水稲との混植条件下では,遮 光以外にも養分競合や密度効果などの影響があり, 本試験の遮光条件下よりもさらに種子生産量は減少 すると考えられる。しかし，寒冷地の水稲の初期生 育は温暖地に比べて緩慢であるため, 生育初期にお ける水稲の影響は必ずしも大きくない。また，前述 したように群落内相対照度には水稲の品種間差がみ られることから，これらの点を考慮した必要除草期 間の設定が望まれる。

温暖地 ${ }^{7)}$ や暖地 ${ }^{99}$ の水稲早期栽培においては水稲 収穫後に再生したイヌホタルイの種子生産について も調査されている。しかし, 本試験の範囲ではイヌ ホタルイおよびタイワンヤマイともに水稲収穫後の 再生は認められず，周辺地区でも水稲収穫後に再生 した個体が種子生産した例は認められなかった。渡 辺ら ${ }^{14)}$ は温暖地の水稲普通期栽培水田では水稲収 穫後のイヌホタルイの種子生産は無視できるとして いるが, 寒冷地においても同様に水稲収穫後のホ夕 ルイ類雑草の再生, 種子生産については無視できる ものと考えられる。

\section{引用 文 献}

1）千坂英雄・伊藤一幸・児嶋 清・古谷勝司・片岡孝 義・宮原益次 1985. 数種水田雑草の埋土種子の 寿命. 雑草研究 30 (別)，133～134.

2）石倉教光・兽我義雄 1978. ホ夕ルイ属雑草の生
態と防除に関する研究. 第 1 報 イヌホタルイ種 子の稔実経過と発芽性. 雑草研究 23, 19 23.

3）岩崎桂三・綿島朝次 1977. ホタルイ,イヌホタル イ及びタイワンヤマイの形態的特徴と TH63 粒 剤の効果. 雑草研究 $22,24 \sim 29$.

4）岩崎桂三・綿島朝次・萩本 宏 1981. ホ夕ルイ, イヌホタルイおよびタイワンヤマイの越冬性と越 冬株から発生した植物の防除. 雑草研究 26 , $104 \sim 110$.

5）岩崎桂三・萩本 宏 1982. ホタルイ,イヌホタル イおよびタイワンヤマイの生育に及ぼす遮光の影 響. 雑草研究 27 (別), 3〜4.

6）岩崎桂三 1983. ホ夕ルイ類の生態と防除. 雑草 研究 28, 163 171.

7）小山 豊 1993. 温暖地の水稲早期栽培における イヌホタルイの種子生産. 雑草研究 38 (別 I), 186 187 .

8）坂本真一・江藤博六 - 梅木佳良 ・村社久米夫・梶本 明 1982. 暖地水稲早期栽培における稲刚後の管 理方式が水田多年生雑草群落の遷移に及ぼす影 響. 第 1 報 耕うん時期の影響. 雑草研究 27 , $259 \sim 263$.

9）坂本真一・江藤博六・梅木佳良・村社久米夫・梶本 明 1982. 水田雑草「ホタルイ」の生態と防除. 宮 崎総農試研報 16, 53 70.

10）住吉 正・佐藤陽一・原田二郎 1991. 東北地域の 水田におけるホタルイ類雑草の分布. 雑草研究 36, 197〜199.

11）住吉 正 1995. 各地産イヌホタルイの種子の発 芽に関する系統間差異. 一東北地域を中心として 一. 日作東北支部報 $38,47 \sim 51$.

12）鈴木光喜 1975. イヌホタルイ種子の発芽特性. 日植調東北支部会報 11, 44 47.

13）高野文夫・鎌田信昭・伊藤吉郎 1976. 多年生雑草 「ホタルイ」の生態と防除について. 東北農業研究 18, 66〜 69.

14）渡辺寛明・宮原益次・芝山秀次郎 1991. 水田にお けるイヌホタルイの生育と種子生産量. 雑草研究 36, $153 \sim 161$.

15）吉岡俊人 1988. 水田雑草夕イヌビエの不斉一発 生に関する種子生態学的研究. 京都大学学位論文, p. $1 \sim 76$. 
Influence of Time of Sowing, Shading and Drainage Conditions on Seed Production of Scirpus juncoides Roxb. subsp. juncoides and S. wallichii Nees

Tadashi Sumiyoshi* and Youichi Sato**

\begin{abstract}
Summary
Influence of environmental conditions on seed production of Scirpus juncoides Roxb. subsp. juncoides and S. wallichii Nees was investigated at Tohoku Natl. Agric. Exp. Stn, Omagari, Akita, Japan. The results were as follows ;

1. The number of seeds of $S$. juncoides and S. wallichii per plant decreased when the time of sowing was delayed, althouh a few seeds were produced even when the seeds were sown on August 11. The number of seeds of both species was reduced by shading, and no seeds of either species sown on August 11

* Tohoku National Agricultural Experiment Station, Omagari, Akita, 014-01, present address: Kyusyu National Agricultural Experiment Station, Chikugo, Fukuoka, 833, Japan

** Kamioka-machi, Akita, 019-17, Japan
\end{abstract}

were produced under 65\% shading (Fig. 1).

2. The number of stems of $S$. juncoides and S. wallichii per plant was reduced when the time of sowing was delayed, and it decreased by shading (Fig. 2). The number of seeds per plant was highly correlated with the number of stems and the stem air-dry weight of both species, among the plants sown on different dates or grown under different shading conditions (Tables 4,5).

3. The number of seeds of $S$. juncoides was reduced by drainage for 1 month, and the effect of drainage varied with the time of treatment in the growing season. The pattern of seed maturation was also affected by drainage (Tables 2, 3).

4. The one-seed weight of $S$. juncoides decreased with the delay in the time of harvest, when the seeds were sown before early June. However, when the seeds were sown after the latter part of June, the one-seed weight increased with the delay in the time of harvest (Tables 2, 3).

Key words: Scirpus juncoides Roxb. subsp. juncoides, Scirpus wallichii Nees, seed production, shading, drainage treatment 